\title{
Characterization of eukaryotic microbial diversity in hypersaline Lake Tyrrell, Australia
}

\section{Karla B. Heidelberg ${ }^{1 *}$, William C. Nelson ${ }^{1}$, Johanna B. Holm ${ }^{1}$, Nadine Eisenkolb $^{1}$, Karen Andrade ${ }^{2}$ and Joanne B. Emerson ${ }^{3}$}

${ }^{1}$ Department of Biology, University of Southern California, Los Angeles, CA, USA

2 Department of Environmental Science, Policy, and Management, University of California, Berkeley, Berkeley, CA, USA

${ }^{3}$ Department of Earth and Planetary Science, University of California, Berkeley, Berkeley, CA, USA

Edited by:

Stefan Bertilsson, Uppsala

University, Sweden

Reviewed by:

Karen G. Lloyd, Aarhus University,

Denmark

Ramiro Logares, Spanish National

Research Council, Spain

Kamran Shalchian-Tabrizi, University

of Oslo, Norway

\section{*Correspondence:}

Karla B. Heidelberg, Department of

Biology, University of Southern

California, 3616 Trousdale Parkway,

AHF 231, Los Angeles, CA 90089,

USA.

e-mail: kheidelb@usc.edu
This study describes the community structure of the microbial eukaryotic community from hypersaline Lake Tyrrell, Australia, using near full length 18S rRNA sequences. Water samples were taken in both summer and winter over a 4-year period. The extent of eukaryotic diversity detected was low, with only 35 unique phylotypes using a $97 \%$ sequence similarity threshold. The water samples were dominated $(91 \%)$ by a novel cluster of the Alveolate, Apicomplexa Colpodella spp., most closely related to $C$. edax. The Chlorophyte, Dunaliella spp. accounted for less than $35 \%$ of water column samples. However, the eukaryotic community entrained in a salt crust sample was vastly different and was dominated (83\%) by the Dunaliella spp. The patterns described here represent the first observation of microbial eukaryotic dynamics in this system and provide a multiyear comparison of community composition by season. The lack of expected seasonal distribution in eukaryotic communities paired with abundant nanoflagellates suggests that grazing may significantly structure microbial eukaryotic communities in this system.

Keywords: microbial eukaryotes, diversity, hypersaline, saltern, Dunaliella, Colpodella, 18S rRNA

\section{INTRODUCTION}

Hypersaline systems are distributed globally in the form of high salt lakes, salt ponds and solar marine salterns, where evaporative processes result in salt concentrations close to and exceeding saturation. Spurred on largely by advances in molecular biology, studies of microbial life in these systems are ideal because diversity is limited by the extreme conditions. In fact, several studies have characterized with great detail the dominant halophilic archaea and bacteria in hypersaline environments (e.g., Ventosa, 2006; Dyall-Smith et al., 2011; Ghai et al., 2011; Harris et al., 2012; Podell et al., 2013). The prokaryotic microbial and viral consortia in hypersaline Lake Tyrrell have been well described using deep metagenomic sequencing (Podell et al., 2013; Narasingarao et al., 2011; Fischer et al., 2012; Emerson et al., 2012, Submitted). These and other studies have placed microbes (used in this sense to include archaea, bacteria and viruses) as essential participants in most biogeochemical processes. However, studies of the diversity and activities of microbial eukaryotic (protistian) assemblages have lagged behind in this and other systems (Caron et al., 2009; Heidelberg et al., 2010). Consequently, the ecological importance that microbial eukaryotes have in food web dynamics in hypersaline systems is poorly understood (Pedrós-Alió et al., 2000; Elloumi et al., 2009). Further, a disproportionate percent of studies on microbial eukaryotes in hypersaline or saltern systems have focused on aspects related to halotolerant green alga, Dunaliella spp. (Oren, 2005; Ma et al., 2010; Ramos et al., 2011). The objectives of this study are to (1) characterize the eukaryotic microbial diversity in Lake Tyrrell in summer and winter over multiple years and (2) to compare water column microbial eukaryotes with those found in benthic salt crusts.

\section{MATERIALS AND METHODS SITE DESCRIPTION}

Lake Tyrrell (LT) is an ephemeral, thalassohaline salt lake with an average surface area of $160 \mathrm{~km}^{2}$ that is located $320 \mathrm{~km}$ NW of Melbourne in semi-arid northwestern Victoria, Australia (Figure 1). The system experiences large seasonal fluctuations in temperature, salinity, oxygen, solar radiation, $\mathrm{pH}$, and water levels. Water levels are controlled by the three sources of percolating brine groundwater, rainfall, and climate (Macumber, 1991, 1992). In winter, the lake contains $\sim 50 \mathrm{~cm}$ water with a salt content ranging from 250 to $300 \mathrm{~g} \mathrm{~L}^{-1}$. In summer, water evaporates, leaving a halite crust up to $7 \mathrm{~cm}$ thick and residual brines with salt concentrations generally $>330 \mathrm{~g} \mathrm{~L}^{-1}$. New brines emerge in springs along the eastern shore with salinities of $\sim 100 \mathrm{~g} \mathrm{~L}^{-1}$, grading into the hypersaline waters toward the center of the lake. Less input comes from direct precipitation, localized runoff, and seasonal input from Lake Tyrrell Creek at the southern point of the lake.

\section{SAMPLING SITE CHARACTERIZATION}

Sample collection dates and site parameters are listed in Table $\mathbf{1 .}$ Average temperatures during sampling periods at the lake ranged from $21^{\circ} \mathrm{C}$ to $37^{\circ} \mathrm{C}$ in the dry, summer periods and $10-12^{\circ} \mathrm{C}$ in the wetter, winter season. The $\mathrm{pH}$ at the sample collection times varied between 6.93 and 7.30 , but fluctuates greatly in other parts of the lake due to acidic groundwater and brine 


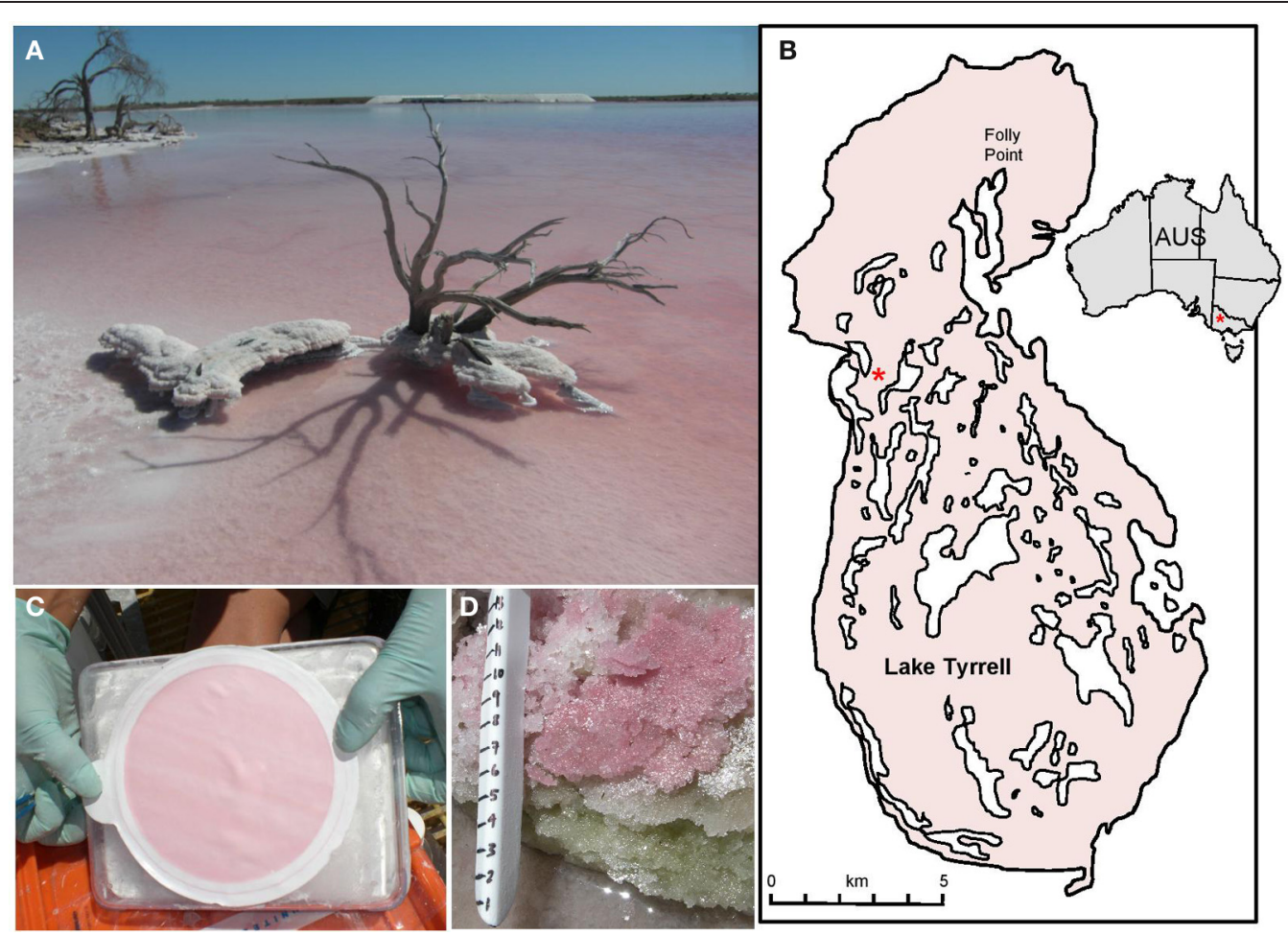

FIGURE 1 | (A) Lake Tyrrell, Victoria Australia. (B) Map showing of the lake within Australia and the sampling site for this project (*). (C) 20-3.0 $\mu$ m water fraction showing filter biomass. (D) Layered salt crust sampled for comparative purposes. Scale shows $1 \mathrm{~cm}$ increments (photo: J. Banfield).

Table 1 | Samples collected in the central part of the lake between 2007 ( $S=$ summer) and 2010 (W = winter).

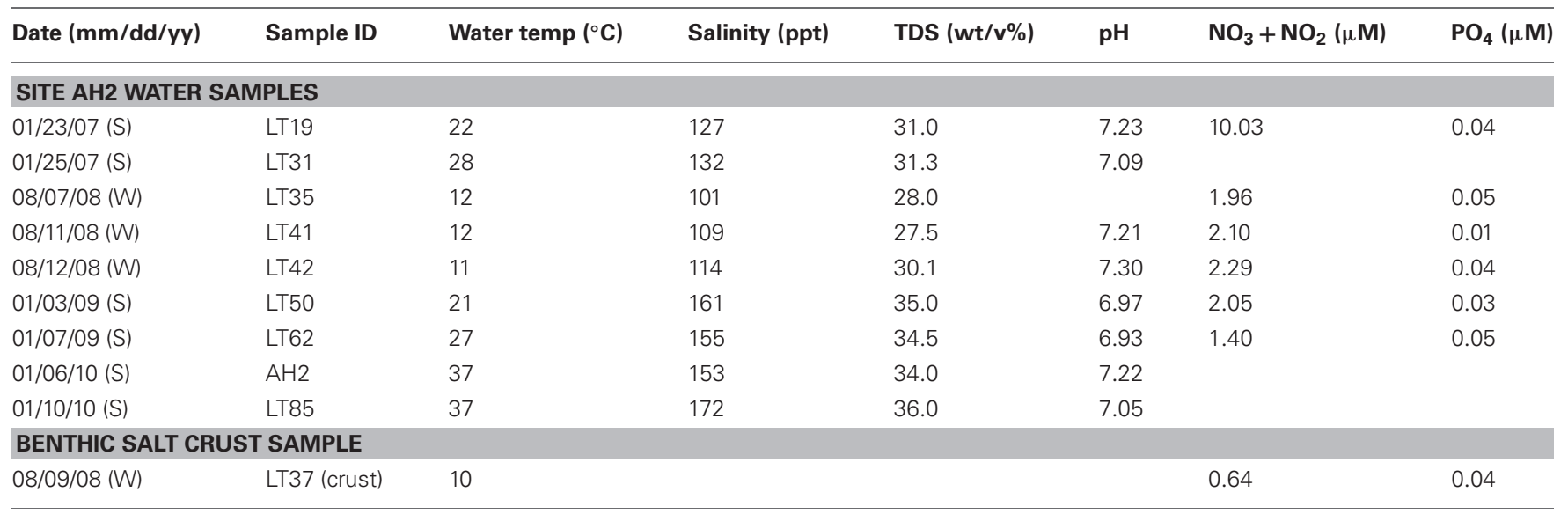

TDS, total dissolved solids; ND, no data.

percolation. Total salinity was obtained by mass after evaporation of a known volume of water. Major ion composition was evaluated using established methods (Winge et al., 1979) at the Australia National University, Canberra, Australia. To evaluate nutrients, replicate $20 \mathrm{~mL}$ water samples were prefiltered through a $0.4 \mu \mathrm{m}$ Nucleopore membrane filter and collected into acid washed polyethylene bottles. Samples were frozen on dry ice in the field and for transport. Samples remained frozen until analysis for nitrite/nitrate (Braman and Hendrix, 1989) and phosphorus (Huerta-Diaz et al., 2005). Nitrate+nitrite concentrations were variable and ranged between 1.40 and $10.3 \mu \mathrm{M}$ in the summer and between 0.64 and $2.29 \mu \mathrm{M}$ in the winter. The system shows continuously low phosphate concentrations between 0.01 and $0.05 \mu \mathrm{M}$. Additional chemical analysis of water samples indicated that the major ions in the water were $\mathrm{Na}^{+}, \mathrm{Cl}^{-}, \mathrm{Mg}^{+2}$, and $\mathrm{SO}_{4}^{-2}$ (unpublished data, J. Brocks).

\section{EUKARYOTIC MICROBIAL SAMPLING}

Sampling for microbial eukaryotes took place at one site in the central region of the lake where a more permanent water body 
is found year around $\left(35^{\circ} 19^{\prime} 09.6^{\prime \prime} \mathrm{S}, 142^{\circ} 47^{\prime} 59.7^{\prime \prime} \mathrm{E}\right.$; Figure 1). Surface water samples $(0.3 \mathrm{~m})$ were sequentially filtered through a $20 \mu \mathrm{m}$ Nitex prefilter then 3.0, 0.8, and $0.1 \mu \mathrm{m} 142 \mathrm{~mm}$ diam. Polyethersulfone filters (Pall Corporation) to obtain fractions enriched for a particular cell size (Narasingarao et al., 2011). Filters were placed in $50 \mathrm{~mL}$ centrifuge tubes with $10 \mathrm{~mL}$ DNA lysis buffer $(100 \mu \mathrm{L}$ TE buffer, $200 \mu \mathrm{L} 1 \mathrm{M}$ EDTA, $200 \mu \mathrm{L} 0.5 \mathrm{M}$ EGTA and $10 \mathrm{~mL}$ DI water). Halite crust samples (Figure 1D) were collected in $50 \mathrm{~mL}$ centrifuge tubes for analysis as a contrast to water column samples. All sampling tubes were frozen on dry ice or in liquid nitrogen for transport.

\section{SEOUENCING}

Genomic DNA was extracted from ten samples using either the MoBio Power Soil DNA kit or a modified phenol extraction (Rusch et al., 2007). 18S rRNA genes were amplified from 10 to $70 \mathrm{ng}$ of DNA from each sample using three universal eukaryotic primers EukA (5'-AACCTGGTTGATCCTGCCAGT-3'), EukB (5'-GATCCTTCTGCAGGTTCACCTAC-3') (Medlin et al., 1988) and the internal primer 528F (5'-GCGGTAATTCCAGCTCCAA$3^{\prime}$ ) (Terrado et al., 2011) and by following the PCR protocol in the TOPO TA Cloning Kit for sequencing (Invitrogen). An ABI thermocycler (model 2720) was used with the following program: $95^{\circ} \mathrm{C}$ for $2 \mathrm{~min}, 35 \mathrm{cycles}$ of $95^{\circ} \mathrm{C}$ for $30 \mathrm{~s}, 55^{\circ} \mathrm{C}$ for $30 \mathrm{~s}$, and $72^{\circ} \mathrm{C}$ for $2 \mathrm{~min}$ and finally $72^{\circ} \mathrm{C}$ for $7 \mathrm{~min}$. PCR products were separated on a $1.5 \%$ agarose gel, and the products of the expected size ( $\sim 1900 \mathrm{bp})$ were excised and purified using the QIAquick gel purification kit (Qiagen) according to the manufacturer's protocol. PCR fragments were further cleaned and concentrated with a Clean and Concentrator-5 Kit (Zymo). Fragments were cloned into the pCR2.1-TOPO Vector using the TOPO TA cloning kit (Invitrogen) and transformed into TOP10-competent cells by electroporation (BTX ECM electroporator, Holliston, MA). Subsequently, the bacterial clones were plated and picked according to standard protocol. Sanger sequencing was performed on an ABI 377 machines at either at the Genome Center at Washington University (samples LT41 and LT42) or at the JCVI (all other samples).

\section{SEOUENCE ANALYSIS}

Raw Sanger sequences were trimmed using Phred at the default error probability cutoff of 0.05 . Putative chimeras were identified in two steps. First, trimmed reads were screened against the full eukaryotic Silva database using UCHIME (Edgar et al., 2011). Sequences from the same clone for which the forward, reverse and internal reads all passed quality and chimera screens were then assembled using the Phred/Phrap/Consed programs (Ewing and Green, 1998; Ewing et al., 1998). Assembled contigs were rescreened for chimeras using Chimera Slayer (Haas et al., 2011). Less $0.2 \%$ of assembled clones were found to be chimeric.

Mothur, v1.26.0. (Schloss et al., 2009) was used for alignments and groupings for alpha diversity analysis. Assembled sequences were aligned against the SILVA database (Quast et al., 2013), screened and trimmed to columns 1109-42,675 of the SILVA alignment. Trimmed sequences were classified into operational taxonomic units (OTUs) using the average neighbor Mothur cluster algorithm. Groupings at 99\%, 97\%, and 95\% nucleotide identity were examined to compare diversity between individual and groups of samples. Taxonomic assignments were made at 97\% identity using the RDP naïve Bayesian classifier and the eukaryotic SILVA database (v.1.08) (Pruesse et al., 2007) with settings of kmer $=9$ analysis and 100 iterations (Wang et al., 2007). Using this method, the relative abundance of groups within communities could be reliably estimated. Similarity of sample communities was examined using MDS plots generated using Log $(\mathrm{x}+1)$ transformed abundance data and Plymouth Routines in Multivariate Ecological Research (PRIMER) software (Clarke and Gorley, 2006).

To further evaluate taxonomic relatedness of LT organisms, Geneious Pro software (v 6.0, Biomatters; http://www.geneious. $\mathrm{com} /$ ) was used to generate ClustalW multiple alignments. Alignments were manually edited and imported into MEGA5 software (Tamura et al., 2011) for generation of maximum likelihood (ML) bootstrapped consensus trees based on the HasegawaKishino-Yano model with five discrete Gamma distributions. Several versions of trees were initially constructed to identify representative LT sequences from larger groups of sequences that clustered together at high percent identity. While not quantitative, this allowed for the development of meaningful trees to evaluate relatedness of LT sequences to other groups.

\section{LIGHT MICROSCOPY}

In summer 2010, 10 water subsamples of $1 \mathrm{~mL}$ each were preserved in 1\% paraformaldehyde and enumerated in a Sedgewick Rafter counting cell slide under $400 \times$ magnification using a compound Olympus, Model BX51 epifluorescent phase microscope (Woelkerling et al., 1976). Cell numbers were calculated from the average number of cells per field the field sample volume, specified by a grid on the bottom of the chamber.

\section{RESULTS}

\section{S rRNA GENE CLONE LIBRARIES}

After quality screening, our dataset contained a total of 2164 near full-length 18S rRNA gene sequences: 1392 from summer samples, 450 from winter samples and an additional 322 sequences from a benthic salt crust sample (Table 2). Sequences have been deposited in NCBI under accession numbers KC485974 to $\mathrm{KC} 488158$.

Water samples were grouped by season and normalized to sequencing effort for several diversity estimates. Using Good's nonparametric coverage estimator (Esty, 1986) for grouped summer and winter samples, we found that our sampling depth captured $98 \%$ of water column diversity at $97 \%$ sequence similarity in both seasons for the water samples. Crust sampling effort was lower (1 sample); however, results from the Good's estimate suggested even with the lower sampling effort, we captured about $96 \%$ of the diversity within the crust sample. Both crust sample diversity and evenness were higher than the pooled summer and winter water samples, even though sampling effort was lower (Table 3).

Sample-based rarefaction analysis (species accumulation curves) was used to show total species richness as a function of sequencing effort. Individual sample analysis and pooled summer 
Table 2 | Summary of Lake Tyrrell near full length 18S rRNA Sanger sequences.

\begin{tabular}{|c|c|c|c|c|c|c|c|}
\hline Date $(\mathrm{mm} / \mathrm{dd} / \mathrm{yr})$ & ID & \# Raw reads & $\%$ Good & $\begin{array}{l}\text { Avg. read } \\
\text { length }\end{array}$ & $\begin{array}{l}\text { \# Assem. (near } \\
\text { full length) }\end{array}$ & $\begin{array}{l}\text { Avg. assem. } \\
\text { length }( \pm S D)\end{array}$ & $\begin{array}{l}\text { Assem. used } \\
\text { in analysis }\end{array}$ \\
\hline 1/23/07 (S) & LT19 & 1152 & 86.9 & 732 & 253 & $1715.4(15.9)$ & 232 \\
\hline 8/07/08 (W) & LT35 & 1152 & 91.8 & 708 & 261 & 1712.5 (12.8) & 259 \\
\hline 8/11/08 (W) & LT41 & 576 & 84.9 & 705 & 118 & $1631.0(56.1)$ & 108 \\
\hline 1/07/09 (S) & LT62 & 1152 & 94.4 & 735 & 233 & $1714.2(18.0)$ & 229 \\
\hline 1/06/10 (S) & $\mathrm{AH} 2$ & 1152 & 91.8 & 767 & 290 & $1709.4(38.1)$ & 214 \\
\hline 1/10/10 (S) & LT85 & 1152 & 89.1 & 805 & 290 & $1706.0(24.4)$ & 288 \\
\hline 8/08/08 (W) & LT37 (crust) & 1152 & 94.4 & 796 & 326 & 1709.3 (15.5) & 322 \\
\hline Total & & & 88.6 & 757.0 & 2226 & 1704 & 2164 \\
\hline
\end{tabular}

Table 3 | OTU diversity statistics for $95 \%$, $97 \%$, and $99 \%$ similarities.

\begin{tabular}{|c|c|c|c|c|c|c|}
\hline Identity (\%) & \# Seqs & OTUs & Goods coverage & Chao (Cl) & Shannon (Cl) & Shannon evenness \\
\hline \multicolumn{7}{|l|}{ SUMMER } \\
\hline 99 & 450 & 52 & 0.900 & $382(170-974)$ & $1.378(1.20-1.55)$ & 0.349 \\
\hline 95 & 450 & 9 & 0.984 & 30 (14-95) & $0.249(0.16-0.34)$ & 0.113 \\
\hline \multicolumn{7}{|l|}{ WINTER } \\
\hline 95 & 450 & 8 & 0.990 & $13(9-40)$ & $0.24(0.15-0.32)$ & 0.114 \\
\hline \multicolumn{7}{|c|}{ WINTER CRUST } \\
\hline 99 & 323 & 55 & 0.860 & $303(148-712)$ & $1.77(1.55-1.99)$ & 0.442 \\
\hline 97 & 323 & 20 & 0.960 & $46(27-119)$ & $0.94(0.78-1.11)$ & 0.316 \\
\hline 95 & 323 & 16 & 0.900 & $34(20-91)$ & $0.64(0.49-0.79)$ & 0.230 \\
\hline
\end{tabular}

$\mathrm{Cl}$, confidence interval. Summer and winter water samples normalized to the lowest sample effort ( $n=450)$. The crust sample (LT37) is included for comparison but has lower sequencing effort than the grouped summer and winter samples.

and winter water samples vs. the halite crust sample also indicate the higher diversity in the crust sample (Figure 2).

\section{COMMUNITY COMPOSITION DETERMINED BY CLONE LIBRARIES}

Taxonomic analysis of the community $18 \mathrm{~S}$ rRNA sequences provided better insight into community composition. Community membership in each sample was characterized by Bayesian inference at $97 \%$ similarity cutoff as described in the methods (Table 4). Detailed Bayesian classification data for each unique sequence is presented in Table S1. Both summer and winter water samples were dominated by Alveolates $(96.3 \%$ of sequences recovered in summer and $96.2 \%$ in winter). Of these, $91.0 \%$ and $91.1 \%$ were closely related to Colpodella spp. in summer and winter water samples, respectively. The Chlorophyte, Dunaliella spp. accounted for $3.4 \%$ of sequences recovered in summer and $2.4 \%$ in winter. Sequences from other groups together made up $<3 \%$ of the community (Figure 3; Table 4). Conversely, analysis of a representative winter halite crust sample was $91.1 \%$ Dunaliella and $7.5 \%$ other groups (Figure 3). Several additional groups were also seen in the halite crust, which were not seen in the water samples (Table 4).
Individual sample communities were compared using multidimensional scaling (MDS) analysis to provide an analysis of the pattern of proximities (i.e., similarities or distances) among samples. When all samples were compared, the benthic crust sample clustered well away from water samples, with a $2 \mathrm{D}$ stress factor of 0.01 (Figure 4A). However when the crust sample was removed, summer and winter water samples had no unique pattern of community clustering (2D Stress 0.05) (Figure 4B), despite physical parameters being variable in temperature (summer $28.67 \pm$ 7.00; winter $11.67 \pm 0.58^{\circ} \mathrm{C}$ ) and salinity (summer $33.63 \pm 2.04$; winter $28.53 \pm 1.38 \mathrm{wt} / \mathrm{v} \%$ ) (Table 1).

\section{PHYLOGENY OF 18S rRNA SEQUENCES}

We generated ML trees to evaluate taxonomic positional of our sequences within specific groups. Given the number of sequences in the dataset, multiple iterations of trees were used to identify a range of representative sequences to compare to sequences in public databases. In many cases, sequences in trees represent additional sequences that are not shown. A full listing of taxonomic assignments using the RDP naïve Bayesian classifier and the eukaryotic SILVA database is in Supplementary Table $\mathbf{1 .}$ 


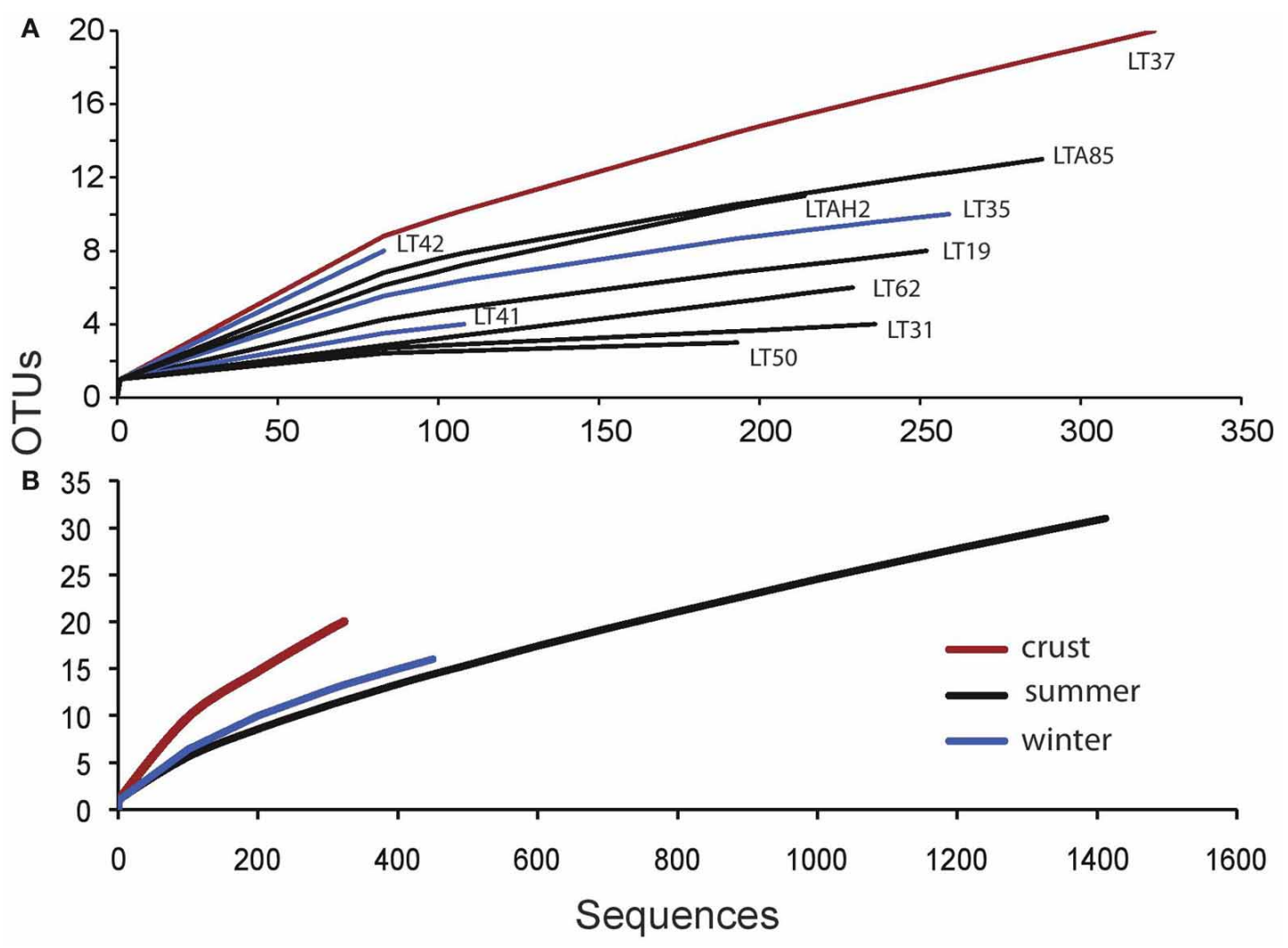

FIGURE 2 | Microbial eukaryote sample rarefaction analysis at $\mathbf{9 7 \%}$ similarity. (A) individual sample curves and (B) grouped sample curves for summer $(n=6)$, winter $(n=3)$, and crust $(n=1)$.

\section{Colpodella spp.}

A preliminary tree of the 1695 Lake Tyrrell colpodellid sequences was used to identify 69 representative sequences for further analysis. These sequences were realigned with reference Colpodella spp. and closely related apicomplexan sequences for the construction of an ML tree. Our sequences formed a discrete node with significant bootstrap support that was closest to a C. edax reference sequence (89.2-96.8\% identity) (Figure 5). Within the node, sequence identities were between 89.1 and $99.9 \%$ similar (Figure 6).

\section{Dunaliella spp.}

Dunaliella-related sequences $(n=325)$ were narrowed to 11 representative sequences and realigned with 13 reference strains. Many Dunaliella strains harbor introns in their 18S rRNA genes (Olmos et al., 2000; Hejazi et al., 2010). Intron regions, if present, were removed from both our sequences and reference sequences for the phylogenetic analysis. Unlike Colpodella (Figures 5 and 6), LT Dunaliella sequences were more diverse. Representative sequences aligned with a variety of described Dunaliella species found in other systems. There was one novel subclade with good support, but evolutionary differences between environmental clones and reference sequences were quite small. No sequence had $>7 \%$ divergence from known species (Figure 7). Representative clones from halite crust samples aligned well with those from water column samples, indicating that the populations are not separate.

\section{Ciliophora sequences}

Our samples included 14 ciliate-related sequences associated with three major groups (Table 4). Of particular note, nine sequences formed a well-supported novel Heterotrichea subclade most closely related to Fabrea salina. These sequences came from both summer and winter samples and both water column and crust samples. Four sequences, all from sample LT85, clustered closely to another hypersaline Plagiopylea ciliate, Trimyema koreanum. The other sequence clustered most closely with a stichotrich ciliate, Orthamphisiella breviseries (Figure 8).

\section{Stramenopile sequences}

No stramenopile sequences were found in water samples, but four were found in the halite crust sample (Table 4). Three of these sequences (LT37_D4, LT37_A5, LT37_B13) formed an independent node deeply within the ancestral Bicoecea, a phagotrophic heterotrophic nanoflagellate group (Figure 9). Our sequences formed an independent group within the Caecitellus genera, which are raptorial gliders commonly found in a variety of marine sediments and commonly thought to be a sister group to the Cafeteriaceae (Cavalier-Smith and Chao, 2006) (Figure 9). The most closely related public sequences to our samples were from 
Table 4 | Relative percent distribution of 18 rRNA sequences into taxonomic groups for each sample using a $97 \%$ cutoff Bayesian classification ( $S=$ summer; $\mathbf{W}=$ winter).

\section{LT19 (S) $\quad$ LT31 (S) $\quad$ LT35 (W) $\quad$ LT41 (W) $\quad$ LT42 (W) $\quad$ LT50 (S) $\quad$ LT62 (S) $\quad$ AH2 (S) $\quad$ LT85 (S) $\quad$ Crust LT37}

\begin{tabular}{|c|c|c|c|c|c|c|c|c|c|c|}
\hline \multicolumn{11}{|l|}{ CHROMALVEOLATA } \\
\hline Apicomplexa, Colpodella spp. & 92.7 & 94.9 & 90.0 & 93.5 & 91.6 & 89.1 & 98.3 & 84.1 & 86.8 & 5.9 \\
\hline Apicomplexa, other & 0.0 & 0.0 & 0.8 & 0.0 & 0.0 & 0.5 & 0.0 & 0.9 & 0.0 & 0.0 \\
\hline Ciliophora, Heterotrichea & 0.4 & 0.0 & 0.0 & 0.0 & 0.0 & 0.0 & 0.4 & 0.0 & 1.0 & 1.2 \\
\hline Ciliophora, Plagiopylea & 0.0 & 0.0 & 0.0 & 0.0 & 0.0 & 0.0 & 0.0 & 0.0 & 0.7 & 0.0 \\
\hline Ciliophora, Stichotrichia & 0.0 & 0.0 & 0.0 & 0.0 & 1.2 & 0.0 & 0.0 & 0.0 & 0.0 & 0.0 \\
\hline Alveolata, other & 4.3 & 0.0 & 7.7 & 0.0 & 0.0 & 0.0 & 0.4 & 14.5 & 8.0 & 2.5 \\
\hline $\begin{array}{l}\text { Chlamydomonadales, } \\
\text { Halosarcinochlamys }\end{array}$ & 0.0 & 0.0 & 0.0 & 1.9 & 2.4 & 0.0 & 0.0 & 0.0 & 0.0 & 2.8 \\
\hline Chlamydomonadales, other & 0.0 & 0.0 & 0.0 & 0.0 & 1.2 & 0.0 & 0.0 & 0.0 & 0.0 & 1.9 \\
\hline \multicolumn{11}{|l|}{ EXCAVATA } \\
\hline $\begin{array}{l}\text { Discoba, Heterolobosea, } \\
\text { Vahlkampfiidea }\end{array}$ & 0.4 & 0.0 & 0.0 & 0.0 & 0.0 & 0.0 & 0.0 & 0.0 & 0.0 & 0.0 \\
\hline $\begin{array}{l}\text { Fungi, Basidiomycota, } \\
\text { Malassezia }\end{array}$ & 0.0 & 0.0 & 0.0 & 0.0 & 0.0 & 0.0 & 0.0 & 0.0 & 0.3 & 0.0 \\
\hline \multicolumn{11}{|l|}{ STRAMENOPILES } \\
\hline Bicoecea, Caecitellus & 0.0 & 0.0 & 0.0 & 0.0 & 0.0 & 0.0 & 0.0 & 0.0 & 0.0 & 0.9 \\
\hline Bacillariophyta & 0.0 & 0.0 & 0.0 & 0.0 & 0.0 & 0.0 & 0.0 & 0.0 & 0.0 & 0.6 \\
\hline Unclassified, Eukarya & 0.0 & 0.4 & 0.0 & 0.0 & 1.2 & 0.0 & 0.4 & 0.0 & 0.0 & 0.6 \\
\hline Number sequences & 232 & 236 & 259 & 108 & 83 & 193 & 229 & 214 & 288 & 322 \\
\hline
\end{tabular}

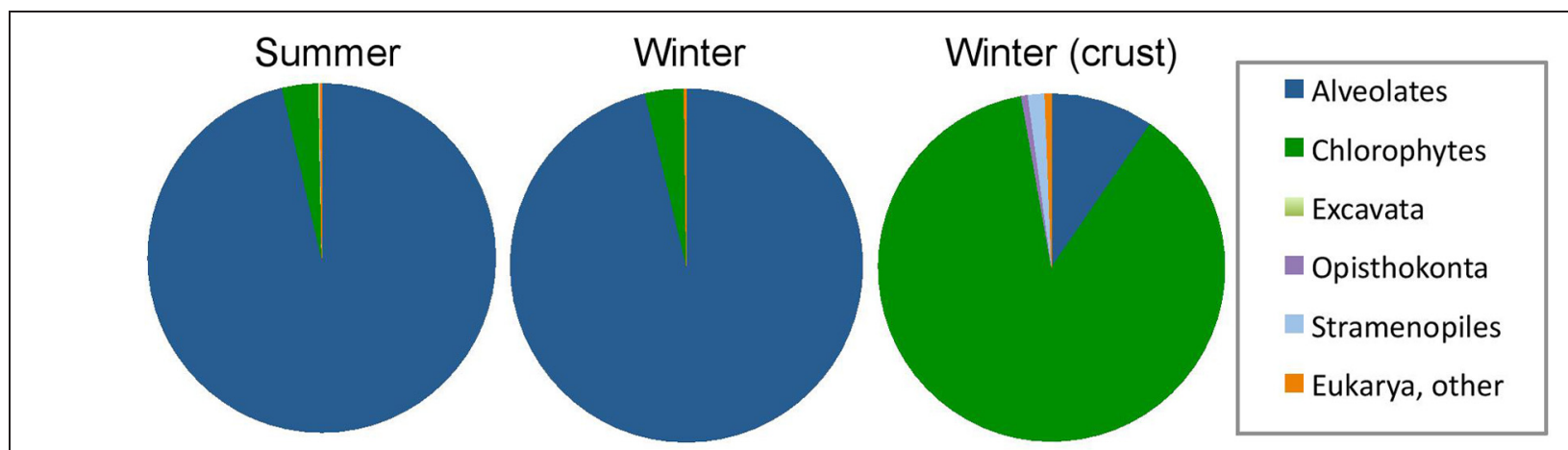

FIGURE 3 | Relative abundance of $18 S$ rRNA sequences from summer samples ( $n=6$ samples; 1392 sequences) and winter samples ( $n=3$ samples; 450 sequences) and a benthic halite crust sample (crust) ( $n=1 ; 322$ sequences). Relative taxonomic abundance data by sample is provided in Table 4 .

marine environments, not hypersaline systems, which supports the notion that that this is a highly adaptive and diverse group. However the distinct grouping of our sequences also suggests that they may represent a distinct assemblage of halotolerant C. parvulus. Distinct halotolerant Bicosoecida groupings have been found for other stramenopile groups (Park and Simpson, 2010).
The sole diatom (Bacillariophyta) sequence in our dataset fell within the Navicula spp. Diatoms like Navicula are commonly found but rarely abundant in hypersaline environments (Jarecki et al., 2006; Potter et al., 2006). We did note two additional diatom species in one of our crust cultures (Figures 10G,I, and J).

There was only one fungal clone in our dataset (LT85_J8), and it belonged to the phyla Basidiomycota. Given the low 


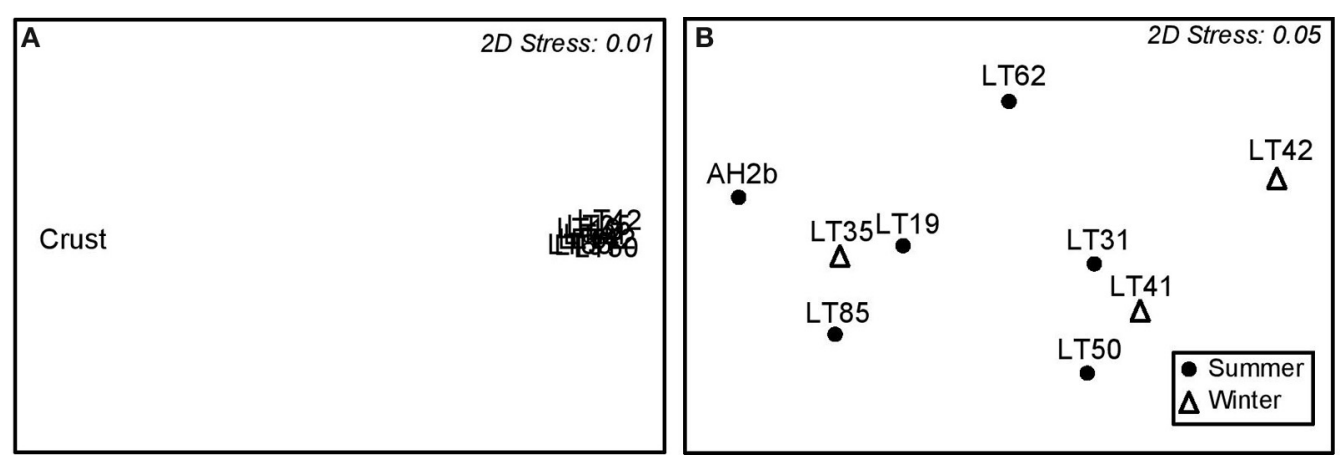

FIGURE 4 | S17 Bray-Curtis similarity multidimensional scaling (MDS) plots showing sample similarity. (A) Clustering of all samples. (B) Clustering of only water samples.

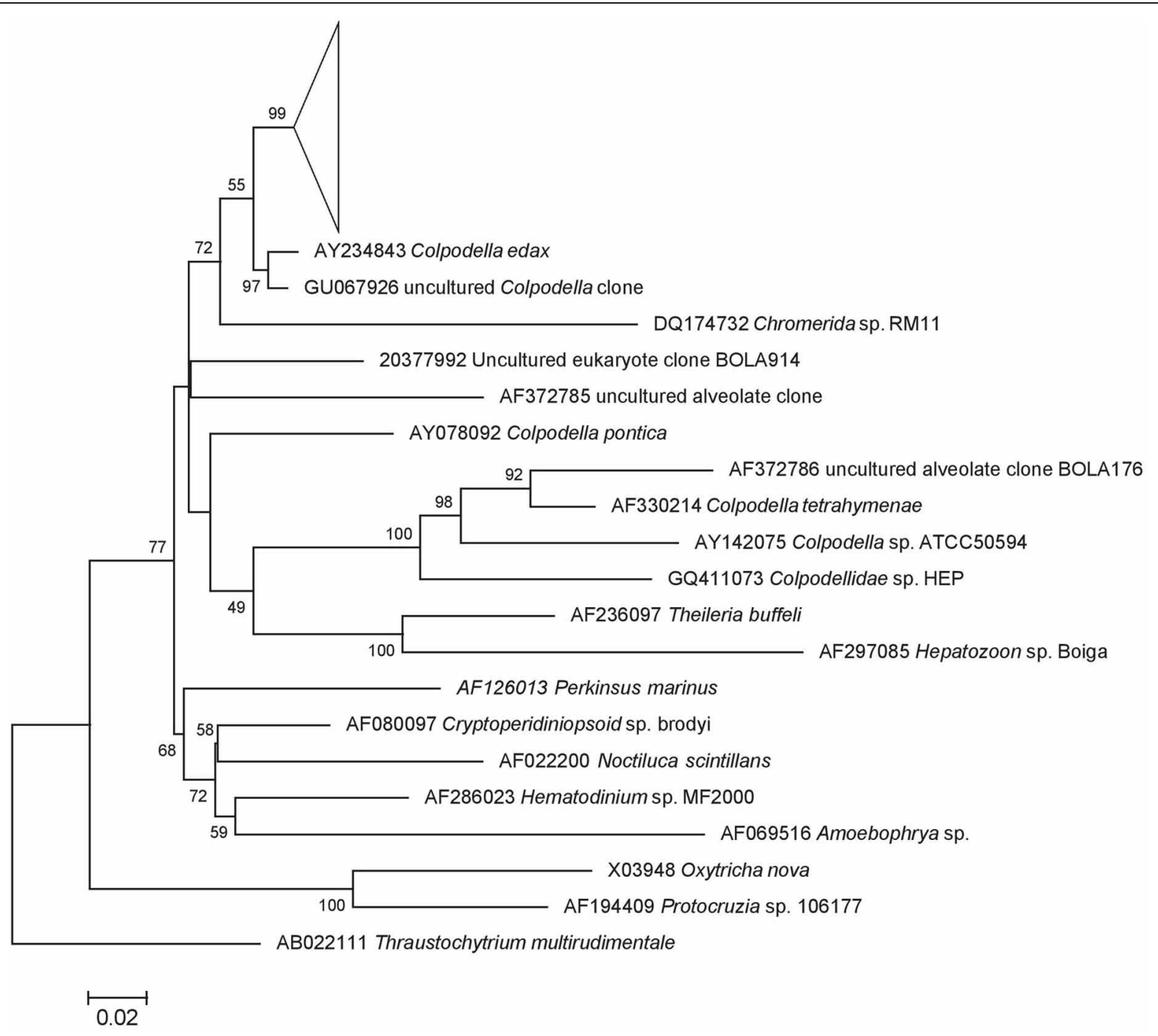

FIGURE 5 | 18 S rRNA ML tree of Colpodella (Apicomplexa) tree with 100 iterated bootstraps. The tree was inferred from an alignment of 89 nucleotide sequences over 1678 bp based using the Hasegawa-Kishino-Yano model in
MEGA5. All representative Lake Tyrrell sequences $(n=69)$ are found within the collapsed node. The scale bar represents the number of substitutions per site. The tree is rooted with Thraustochytrium multiudimentale. 


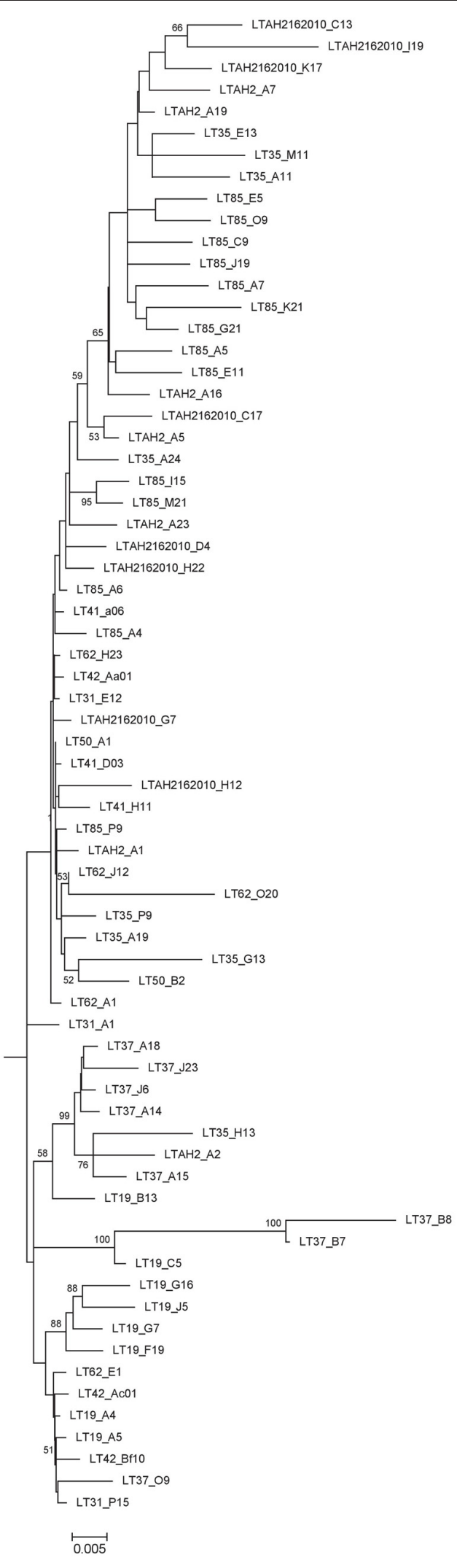

FIGURE 6 | Expansion of 69 Lake Tyrrell Colpodella sequences from Figure 5. abundances, this group probably does not exert a significant contribution to the heterotrophy in the system. However, our PCR primer sets may not be ideally suited for characterizing fungal communities. Fungi commonly found in other hypersaline water are black yeasts and species of the Ascomycetes Eurotium and some Cladosporium and Basidiomycete species (GundeCimerman et al., 2000; Butinar et al., 2005a,b; Zalar et al., 2005; Cantrell et al., 2006), but the understanding of their potential ecological role or input is still limited. Many fungal strains found in hypersaline samples also commonly occur in adjacent agricultural soils, which may suggest that fungal 18S rRNA signatures may be coming from land-based sources rather than local aquatic populations.

\section{MICROSCOPIC ANALYSIS OF COMMUNITY COMPOSITION IN WATER SAMPLES}

Microscopic analysis of water samples from the 2010 summer samples indicated an average abundance of $201 \pm 121$ SD cells $\mathrm{ml}^{-1}$ (85\%) for Colpodella spp. and $32 \pm 12$ SD cells $\mathrm{ml}^{-1}(14 \%)$ for Dunaliella spp. Most cells of freshly collected Dunaliella were red, carotenoid-rich flagellated cell or unflagellated aplanospores (cysts) (Figure 10A,B). Samples collected in summer 2010 but maintained in cultures for 1 year at room temperature and lower salinities had a higher proportion of green cells (Figures 10C,D). All other groups combined made up $\sim 1 \%\left(2 \pm 1\right.$ SD cells $\left.\mathrm{ml}^{-1}\right)$ of the population. Counts were in fairly good agreement with clone library results.

\section{DISCUSSION}

Hypersaline systems are overwhelming dominated by prokaryotes, with communities dominated by the haloarchaea. However, eukaryotic organisms are also commonly present and play important ecological roles. Unlike prokaryotic communities, we did not see seasonal shifts in eukaryotic microbial communities corresponding to changes in physical parameters such as temperature and salinity. Summer 2007 prokaryotic abundances characterized microscopically averaged $1.6 \times 10^{7}$ cells $\mathrm{mL}^{-1}$, with Haloarchaea making up $90 \%$ of the community and halophylic bacteria comprising 10\% (Narasingarao et al., 2011). These were in agreement with community characterizations using genomic data. Summer communities averaged over multiple years were comprised of about 94\% Haloarchaea (mostly Haloquadratum, Halorubrum and Nanohaloarchaea) and 6\% halophilic bacteria (mostly Salinibacter). In winter the halophilic bacteria increased up to $32 \%$ of the community and overall diversity increased (Emerson et al., submitted). Interestingly, we found little seasonality in the microbial eukaryotic community structure despite wide temperature and salinity differences. This may suggest that grazing by heterotrophic flagellates in the system is more important than environmental factors in maintaining eukaryotic community structure.

Heterotrophic nanoflagellates are commonly found in hypersaline environments, and grazing has been shown to play important roles in other studies in re-mineralizing nutrients and in controlling prokaryotic and Dunaliella communities (Post et al., 1983; Patterson and Simpson, 1996; Park et al., 2003). For example, Park et al. estimated that a heterotrophic nanoflagellate in a 


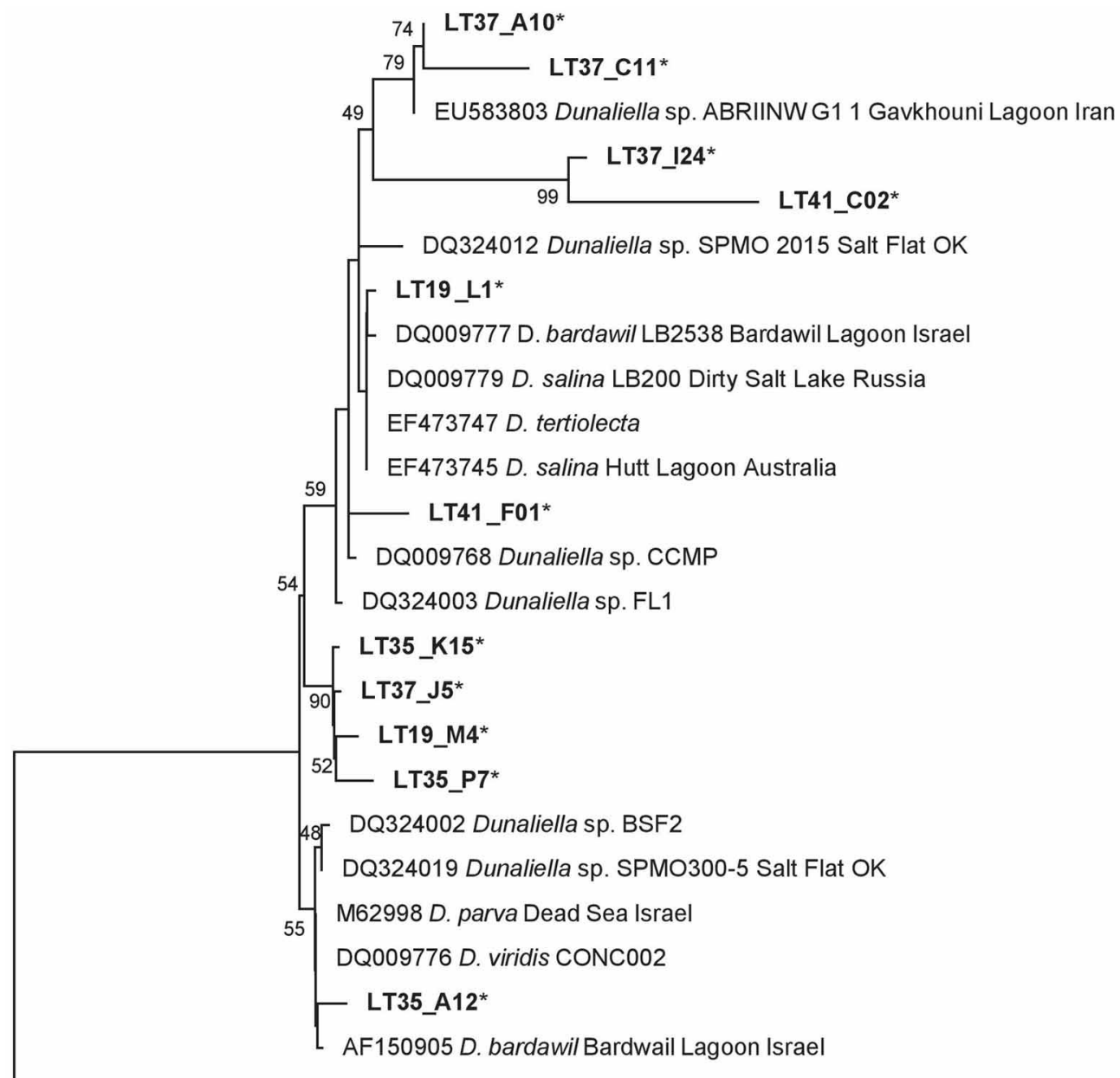

AB511836 Chlamydomonas reinha

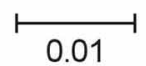

FIGURE 7| 18S rRNA ML of Dunaliella sequences based on a 1496 bp alignment, including 11 representative LT sequences (*) with 13 Dunaliella public reference sequences. The tree is drawn to scale, with branch lengths measured in the number of substitutions per site using the Hasegawa-Kishino-Yano model and MEGA5 as described in the methods. Bootstrap values are shown as the percentages of 100 trees inferred in the analysis. The tree was rooted with Chlamydomonas reinha.
Korean saltern could control prokaryotic communities with grazing rates high enough to turn over communities every 9-48 days. Intense grazing has also been shown to control Dunaliella populations in other hypersaline systems (Brock, 1975; Dolapsakis et al., 2005).

Colpodellids are small $(12-19 \mu \mathrm{m})$, free-living predatory flagellates that are a sister group to the Apicomplexa (Kuvardina et al., 2002; Leander and Kuvardina, 2003). They have been identified in other hypersaline systems but historically have been considered a minor component in hypersaline environments (GuixaBoixareu et al., 1996). However, in Lake Tyrrell, Colpodella dominated the microbial eukaryotic assemblage in the water for both clone libraries and microscope counts (Figure 3; Table 4). Cell densities in January 2010 samples were 201 cells $\mathrm{mL}^{-1}(9 \times$ greater than Dunaliella cells in the same samples). While the difference is greater when evaluating molecular sampling $(31 \times)$, the general community composition reflected in the amplicon libraries was similar to microscopic enumerations. Differences could be attributed to differences in SSU rRNA gene copy number (Prokopowich et al., 2003; Medinger et al., 2010) or factors associated with $18 \mathrm{~S}$ rRNA clone library construction biases (Koid et al., 2012). They have been observed to feed on a variety of other protists, but their ecology is generally not well understood (Post et al., 1983; Simpson and Patterson, 1996). Colpodellids generally feed by sucking prey contents partially or completely using a rostrum (Figure 10F) (Mylnikov, 2009), however those observed in this study readily ingested whole Dunaliella cells (Figure 10E).

Other heterotrophs were found in the lake for example (Figure 10H), although at much less frequency than Colpodella. Samples also had sequences that were closely related to Trimyema koreanum, a Plagiopylea ciliate first identified in a Korean saltern. Other ciliates were more closely related to Fabrea salina, a ciliate 


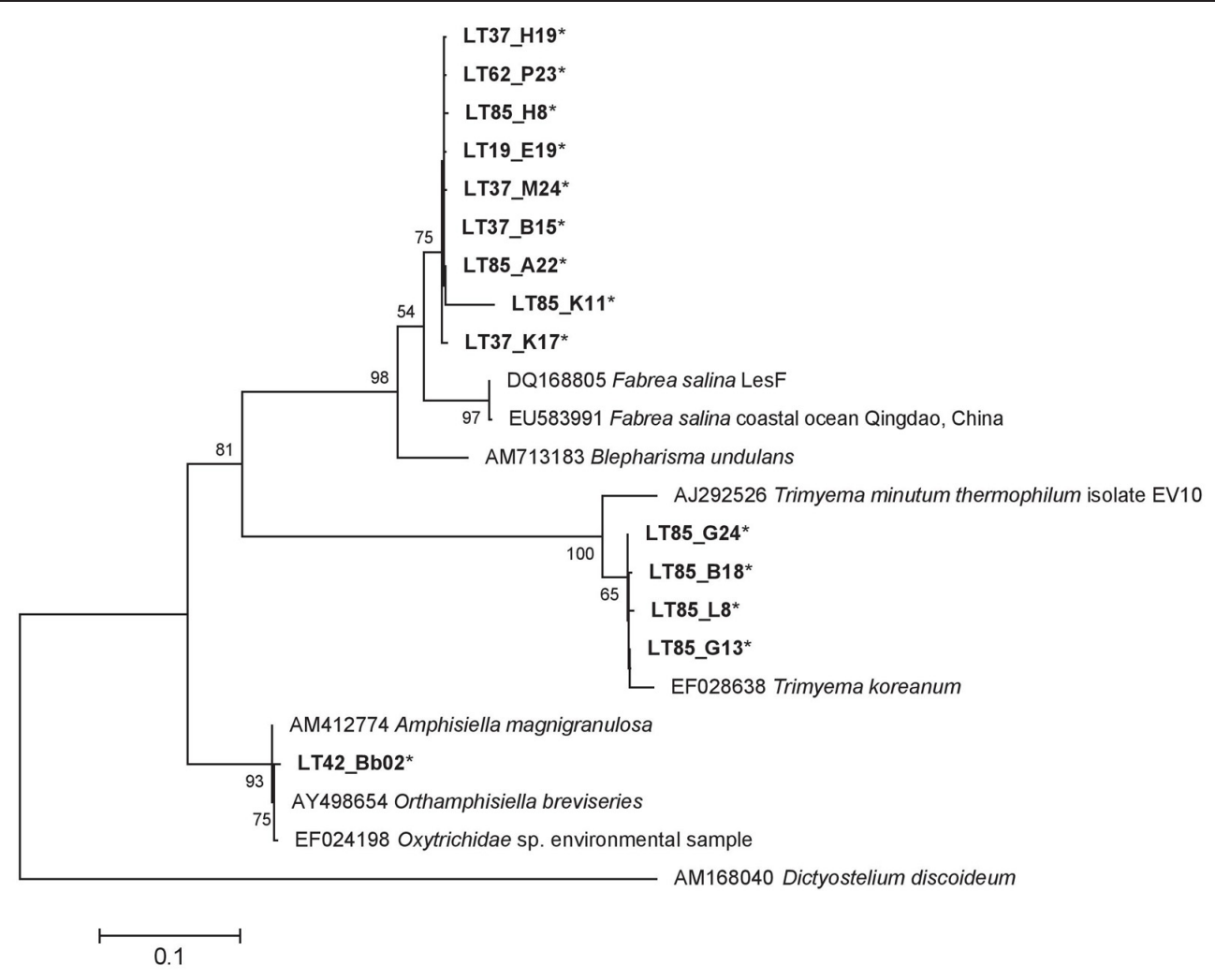

FIGURE 8 | 18S rRNA ML tree of Ciliophora sequences generated from 23 sequences and a $\mathbf{1 3 9 0}$ bp alignment. There were 14

representative Lake Tyrell sequences $(*)$ and 8 reference sequences. The tree is drawn to scale, with branch lengths measured in the number of substitutions per site using the Hasegawa-Kishino-Yano model and MEGA5 as described in the methods. Bootstrap values are shown as the percentages of 100 trees inferred in the analysis. The tree was rooted with Dictyostelium discoideum. with remarkable tolerance to high salinities that has been routinely documented in hypersaline systems worldwide (Hauer and Rogerson, 2005) (Figure 8). Both T. koreanum and F. salina consume prokaryotes and have been shown to control populations of Dunaliella spp. (Post et al., 1983; Borowitzka et al., 1985; Dolapsakis et al., 2005; Cho et al., 2008). We propose that highly abundant co-occurring Colpodella sp. and other heterotrophs may exert considerable grazing pressure on communities of Dunaliella and prokaryotes.

Dunaliella have been described from a wide variety of habitats with salinities between $10 \%$ and saturation reviewed by Ben-Amotz et al. (2009) and Oren (2005). Densities have been reported as $1-3 \times 10^{4}$ cells $\mathrm{mL}^{-1}$ in a salt saturated lagoon in Baja, Mexico (Olmos et al., 2009); 4-12.5 $\times 10^{3}$ cells $\mathrm{mL}^{-1}$ in a northern Greece solar saltern (Dolapsakis et al., 2005); and $4 \times 10^{4} \mathrm{~mL}^{-1}$ during a surface water bloom in the Dead Sea, with an order of magnitude lower in deeper more saline water (Oren et al., 1995; Kaplan and Friedman, 2007). In relation to these studies, cell abundances in summer 2010 water samples were low $\left(32 \pm 12 \mathrm{SD}\right.$ cells $\left.\mathrm{ml}^{-1}\right)$. However, the sequence data showed a remarkably consistent summer and winter community composition in the water (Figure 3; Table 4), suggesting that differences in temperature and salinity may not be the main structuring factor controlling their abundances as has been suggested for other systems. Interestingly the sequence data of the halite crust indicated that Dunaliella dominated the community assemblage (Figure 3, Table 4). The crust may provide a refuge from predation and allow Dunalliella populations to dominate in this habitat.

Some species of Dunaliella over-produce carotenoids, especially $\beta$-carotene, and glycerol to balance the external osmotic pressure and to protect the chlorophyll and the cell DNA from the high irradiance from Ben-Amotz and Avron (1973), Avron and Ben-Amotz (1979), Oren et al. (1995), and Borowitzka (2007). Stressed cells appear orange-red rather than green. The majority of the observed cells from the 2010 summer samples were bright orange and round (Figure 10A). However after these sampled were maintained in laboratory cultures but transitioned to lower temperatures and salinities the Dunaliella in the cultures were mostly pear-shaped and green from chlorophyll pigments in their chloroplasts (Figures 10C,D). This suggests that either Dunaliella are quite physiologically plastic and when not stressed, and cells return to a more preferred growth state, or that the composition of the Dunaliella species community shifted in the altered environmental condition. The lake has a mixture of Dunaliella species (Figure 7). Some of our sequences align closely to D. parva and $D$. viridis, which are not known to readily alter their morphology and color at high salinities. Other sequences in our dataset align closer to other species (e.g., D. salina) that do assume an orange coloration and round shape when stressed 


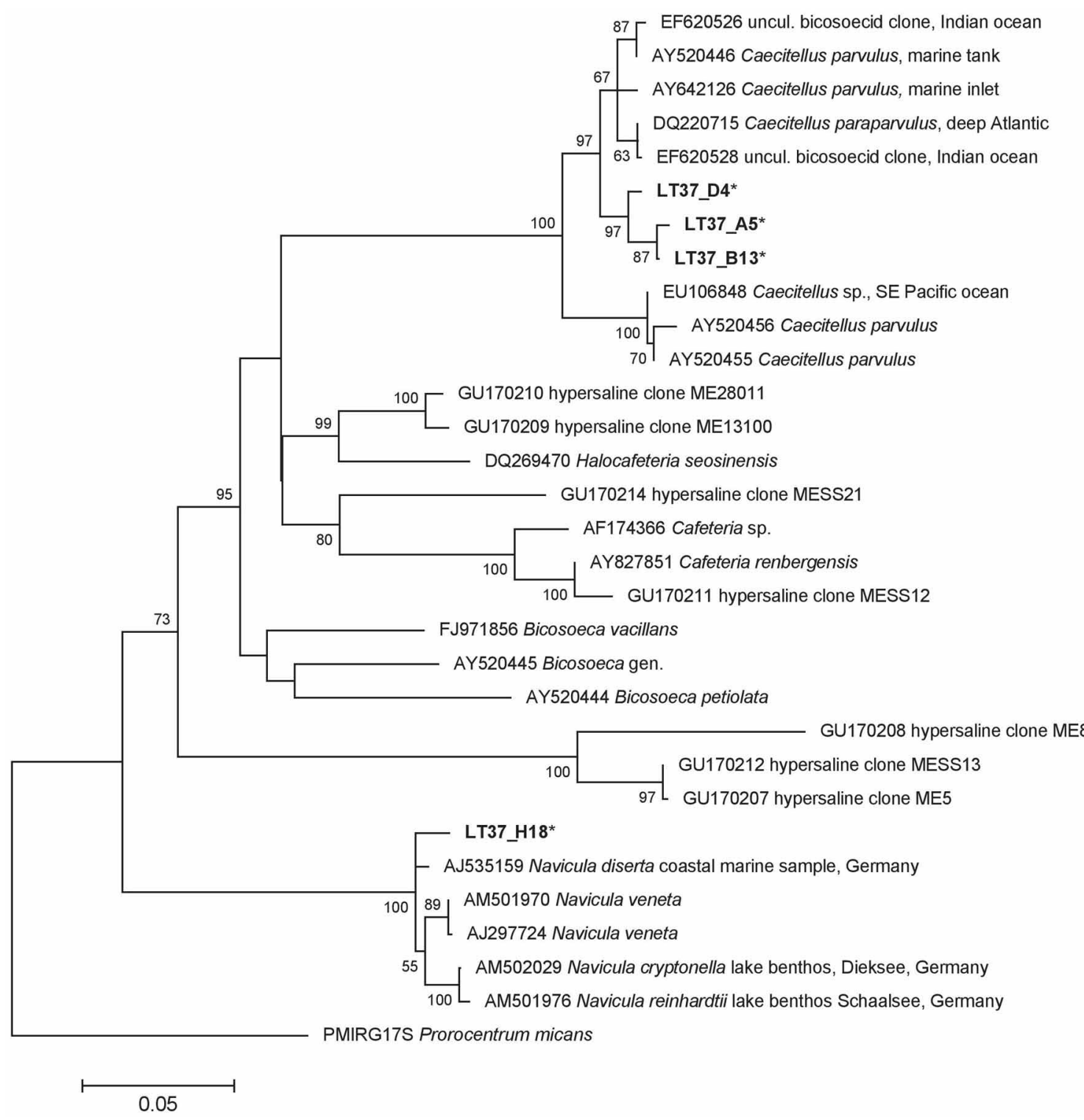

FIGURE 9 | 18S rRNA ML tree of stramenopiles from 31 sequences and a $\mathbf{1 5 1 9}$ bp alignment. The tree was generated using a Hasegawa-Kishino-Yano model and MEGA5 as described in the methods. There were 4 Lake Tyrrell sequences (*). The tree is drawn to scale, with branch lengths measured in the number of substitutions per site. Bootstrap values are shown as the percentages of 100 trees inferred in the analysis, and the tree was rooted with the dinoflagellate, Prorocentrum micans. (reviewed by Borowitzka, 1990). Dunaliella are considered potentially important in hypersaline systems as both primary producers and because the excess glycerol produced by some Dunaliella can be used as a substrate by Archaea (Elevi Bardavid et al., 2008). Future evaluations of the changes in Dunaliella community structure in different seasons or in different parts of the lake would be helpful in elucidating differences in ecological roles of the different species within the lake.

\section{CONCLUSION}

The presence of microbial eukaryotes in hypersaline environments is not new. However, data on quantitative identification of communities of eukaryotic assemblages is limited. In addition to providing a phylogenetic survey of taxa based on near full-length $18 \mathrm{~S}$ rRNA sequences, we found several novel groupings of organisms. Logares et al. (2006) suggested that relatively isolated systems would promote opportunities for rapid evolutionary divergence. It is unclear if these sequences are truly diverging from all other sequences or if the unique clustering of sequences is more of an artifact of a relatively small public database of characterized eukaryotic sequences with adequate length to reliably evaluate phylogenetic histories. This topic could be explored further with a more detailed focus on specific groups. 

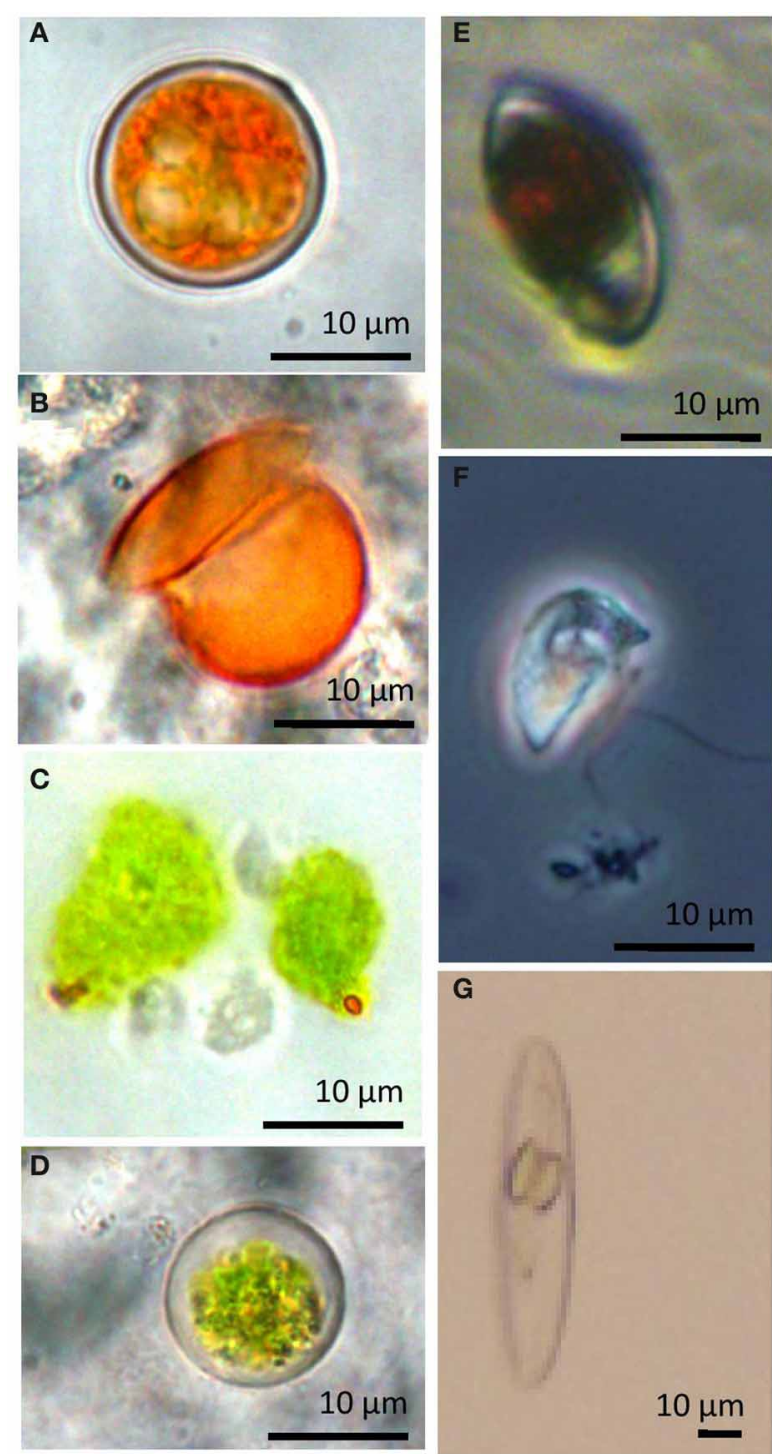

G

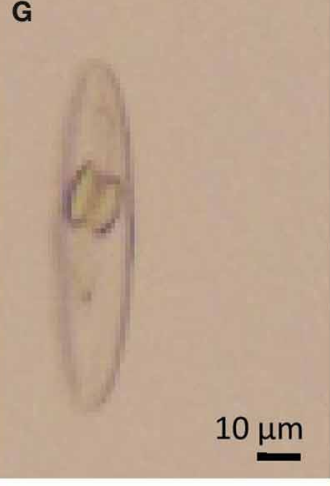

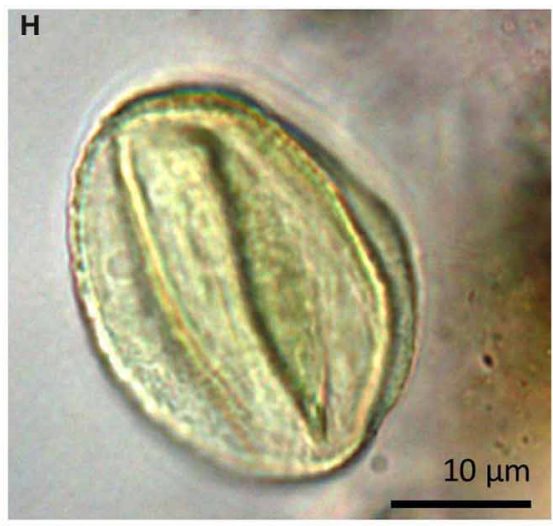
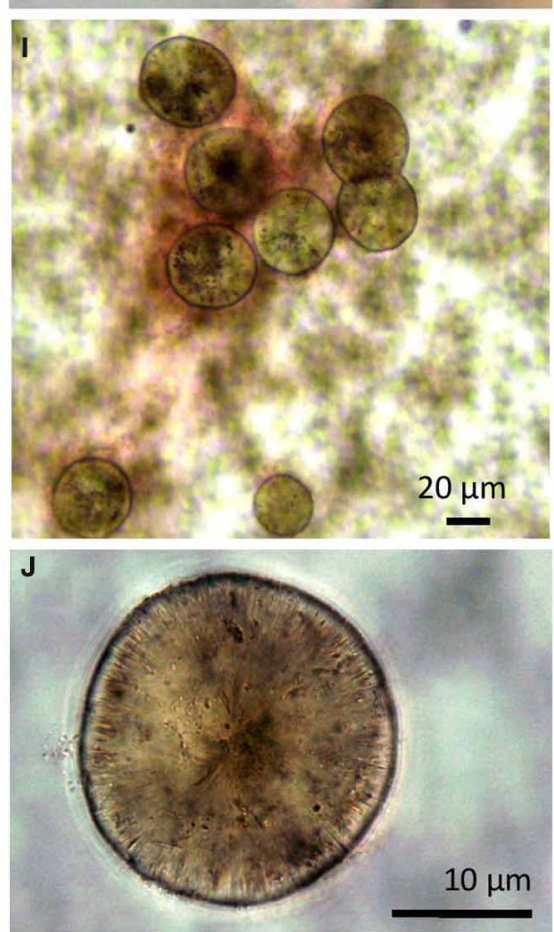

FIGURE 10 | Select light micrographs of lake protists collected in January 2010 when cells were exposed to high salinities and

temperatures. (A) Microscopic images showing Dunaliella cell aplanospores (cycts) and (B) an empty cell coat (C,D) Cells observed in cultures 12 months after collection (E) Heterotrophic flagellate, Colpodella sp. with ingested Dunaliella cell (F) Colpodella spp. (G) unidentified diatom observed in the halite crust sample. (H) unidentified ciliate from water sample. $(\mathbf{I}, \mathbf{J})$ unidentified diatoms from water samples.
We also saw surprisingly minimal seasonal change in water column community structure, which may indicate that the system is controlled by top down grazers. However, the relative distribution of microbial eukaryotic communities living in the benthic halite crust was very different from water column communities. The crust may provide a refuge from predation for Dunaliella by the colpodellids and ciliates. The higher concentration of Dunaliella in the crust may also indicate that the crusts are an important source of autotrophic production. However, further work is needed to fully assess the role of primary production in the lake and the role that grazing has on the distribution of prokaryotes and autotrophic microbial eukaryotes (e.g., Dunaliella) within the system. These data provide the baseline information needed to further study the ecological context of the roles of microbial eukaryotes in the system.

\section{SUPPLEMENTARY MATERIAL}

The Supplementary Material for this article can be found online at: http://www.frontiersin.org/Aquatic_Microbiology/10.3389/ fmicb.2013.00115/abstract

\section{ACKNOWLEDGMENTS}

We wish to thank J. Banfield and C. Jones (UC Berkeley), EE Allen (UCSD, SCRIPPS), E. Scott (USC) and S. Wells (Australian National University) and E. Smith, C. M. Heidelberg and J. G. Heidelberg for assistance with field work; 
J. Brocks (ANU) assisted with sampling and provided salinity ion composition analysis; E. Vidar assisted with laboratory culture analysis. T. Gunderson (USC) assisted with nutrient analysis. Mike Dyall-Smith provided field equipment and lab use at the University of Melbourne; Cheetham Salt Works (Sea Lake, Australia) provided permission to collect samples. Funding for

\section{REFERENCES}

Avron, M., and Ben-Amotz, A. (1979). "Metabolic adaptation of the alga Dunaliella to low water activity," in Strategies of Microbial Life in Extreme Environments, ed M. Shilo (Berlin: Dahlem Konferenzen), 83-91.

Ben-Amotz, A., and Avron, M. (1973). The role of glycerol in the osmotic regulation of the halophilic alga Dunaliella parva. Annu. Rev. Plant Physiol. 51, 875-878.

Ben-Amotz, A., Polle, J. E. W., and Rao, D. V. S. (2009). The Alga Dunaliella: Biodiversity, Physiology, Genomics, and Biotechnology. Enfield, NH: Science Publishers.

Borowitzka, M. (2007). The taxonomy of the genus Dunaliella (Chlorophyta, Dunaliellales) with emphasis on the marine and halophilic species. J. Appl. Phycol. 19, 567-590.

Borowitzka, M. A. (1990). "The mass culture of Dunaliella salina," in Technical Resource Papers Regional Workshop on the Culture and Utilization of Seaweads. Vol. 2. Fisheries and Aquaculture Department. FAO Corporate Document Repository. Available online at: http://www.fao.org/docrep/ field/003/AB728E/AB728E00.htm

Borowitzka, L. J., Moulton, T. P., and Borowitzka, M. A. (1985). "Salinity and the commercial production of beta-carotene from Dunaliella salina," in Algal Biomass: An Interdisciplinary Perspective, eds W. J. Barclay and R. McIntosh (Verduz: J. Cramer Verlag), 217-222.

Braman, R. S., and Hendrix, S. A (1989). Nanogram nitrite and nitrate determination in environmental and biological materials by vanadium (III) reduction with chemiluminescence detection. Anal. Chem. 61, 2715-2718.

Brock, T. D. (1975). Salinity and the ecology of Dunaliella from Great Salt Lake. Microbiology 89, 285-292.

Butinar, L., Santos, S., SpencerMartins, I., Oren, A., and Gunde-Cimerman, N. (2005a). Yeast diversity in hypersaline habitats. FEMS Microbiol. Lett. 244, 229-234.
Butinar, L., Zalar, P., Frisvad, J. C., and Gunde-Cimerman, N. (2005b). The genus Eurotium - members of indigenous fungal community in hypersaline waters of salterns. FEMS Microbiol. Ecol. 51, 155-166.

Cantrell, S. A., Casillas-Martínez, L., and Molina, M. (2006). Characterization of fungi from hypersaline environments of solar salterns using morphological and molecular techniques. Mycol. Res. 110, 962-970.

Caron, D. A., Worden, A. Z., Countway, P. D., Demir, E., and Heidelberg, K. B. (2009). Protists are microbes too: a perspective. ISME J. 3, 4-12.

Cavalier-Smith, T. T., and Chao, E. E.-Y. (2006). Phylogeny and megasystematics of phagotrophic heterokonts (kingdom Chromista). J. Mol. Evol. 62, 388-420.

Cho, B. C., Park, J. S., Xu, K., and Choi, J. K. (2008). Morphology and molecular phylogeny of Trimyema koreanum $n$. sp., a ciliate from the hypersaline water of a solar saltern. J. Eukary. Microbiol. 55, 417-426.

Clarke, K. R., and Gorley, R. N. (2006). PRIMER v6: user Manual/Tutorial. Primer-E Ltd Plymouth. 2006.

Dolapsakis, N., Tafas, T., Abatzopoulos, T., Ziller, S., and EconomouAmilli, A. (2005). Abundance and growth response of microalgae at Megalon Embolon solar saltworks in northern Greece: an aquaculture prospect. J. Appl. Phycol. 17, 39-49.

Dyall-Smith, M. L., Pfeiffer, F., Klee, K., Palm, P., Gross, K., Schuster S. C., et al. (2011). Haloquadratum walsbyi: limited diversity in a global pond. PLoS ONE 6:e20968. doi: 10. 1371/journal.pone.0020968

Edgar, R. C., Haas, B. J., Clemente, J. C., Quince, C., and Knight, R. (2011). UCHIME improves sensitivity and speed of chimera detection. Bioinformatics 27, 2194-2200.

Elevi Bardavid, R., Khristo, P., and Oren, A. (2008). Interrelationships between Dunaliella and halophilic prokaryotes in saltern crystallizer ponds. Extremophiles 12, 5-14.

Elloumi, J., Carrias, J.-F., Ayadi, H., Sime-Ngando, T., and Bouaïn, A. (2009). Communities structure of the planktonic halophiles in the

this work was provided by NSF MCB (Award \#0626526 to Banfield, Allen and Heidelberg), the USC Women in Science and Engineering program, which provided travel funds for Eisenkolb, and the USC Wrigley Institute for Environmental Studies for intern housing. Ella Sieradzki and three anonymous reviewers provided comments that significantly improved the manuscript.

solar saltern of Sfax, Tunisia. Estuar Coast Shelf Sci. 81, 19-26.

Emerson, J. B., Thomas, B. C., Andrade K., Allen, E. E., Heidelberg, K. B., and Banfield, J. F. (2012). Dynamic viral populations in hypersaline systems as revealed by metagenomic assembly. Appl. Environ. Microbiol. $78,6309-6320$

Esty, W. W. (1986). The efficiency of good's nonparametric coverage estimator. Ann. Stat. 14, 1257-1260.

Ewing, B., and Green, P. (1998). Basecalling of automated sequencer traces using Phred. II. Error probabilities. Available online at: http:// genome.cshlp.org/content/8/3/186. short.

Ewing, B., Hillier, L., Wendl, M., and Green, P. (1998). Base-calling of automated sequencer traces using Phred. I. Accuracy assessment. Genome Res. 8, 175-185.

Fischer, S., Maier, L.-K., Stoll, B. Brendel, J., Fischer, E., Pfeiffer, F. et al. (2012). An archaeal immune system can detect multiple protospacer adjacent motifs (PAMs) to target invader DNA. J. Biol. Chem. 287, 33351-33363.

Ghai, R., Pašič, L., Fernández, A. B. Martin-Cuadrado, A.-B., Mizuno, C. M., McMahon, K. D., et al. (2011). New abundant microbia groups in aquatic hypersaline environments. Sci. Rep. 1:135. doi: 10 . 1038/srep00135

Guixa-Boixareu, N., Calderon Paz, J. I., Heldal, M., Bratbak, G., and PedrósAlió, C. (1996). Viral lysis and bactivory as prokaryotic loss factors along a salinity gradient. Aquatic Microb. Ecol. 11, 215-227.

Gunde-Cimerman, N., Zalar, P., de Hoog, S., and Plemenitaš, A. (2000). Hypersaline waters in salterns: natural ecological niches for halophilic black yeasts. FEMS Microbiol. Ecol. 32, 235-240.

Haas, B., Gevers, D., Earl, A. Feldgarden, M., Ward, D., Giannokous, G., et al. (2011) Chimeric 16S rRNA sequence formation and detection in Sanger and 454-pyrosequenced PCR amplicons. Genome Res. 21, 494-504.

Harris, J. K., Caporaso, J. G., Walker, J. J., Spear, J. R., Gold, N. J., Robertson, C. E., et al. (2012). Phylogenetic stratigraphy in the
Guerrero Negro hypersaline microbial mat. ISME J. 1, 11.

Hauer, G., and Rogerson, A. (2005). "Heterotrophic protozoa from hypersaline environments," in Adaptation to Life at High Salt Concentrations in Archaea, Bacteria, and Eukaryal, eds N. Gunde-Cimerman, A. Oren, and A. Plemenitaš (Dordrecht: Springer-Verlag), 522-539.

Heidelberg, K. B., Gilbert, J. A., and Joint, I. (2010). Marine genomics: at the interface of marine microbia ecology and biodiscovery. Microb. Biotechnol. 3, 531-543.

Hejazi, M. A., Barzegari, A., Gharajeh, N., and Hejazi, M. S. (2010). Introduction of a novel $18 \mathrm{~S}$ rDNA gene arrangement along with distinct ITS region in the saline water microalga Dunaliella. Saline Syst. 6:4. doi: 10.1186/1746-1448-6-4

Huerta-Diaz, M., Tovar-Sanchez, A., Filippelli, G., Latimer, J., and Sanudo-Wilhelmy, S. (2005). A combined cdb-magic method for the determination of phosphorus associated with sedimentary iron oxyhydroxides. Appl. Geochem. 20, 2108-2115.

Jarecki, L., Burton-MacLeod, S. M., and Garbary, D. J. (2006). Ecology of algal mats from hypersaline ponds in the British Virgin Islands. Algae 21, 235-243.

Kaplan, I. R., and Friedman, A. (2007). Biological productivity in the Dead Sea: part 1 microorganisms in the water column. Isr. J. Chem. 8 , 513-528.

Koid, A., Nelson, W. C., Mraz, A., and Heidelberg, K. B. (2012). Comparative analysis of eukaryotic marine microbial assemblages from 18S rRNA gene and gene transcript clone libraries by using different methods of extraction. Appl. Environ. Microbiol. 78, 3958-3965.

Kuvardina, O. N., Leander, B., Aleshin, V., Mylnikov, A., Keeling, P., and Simdyanov, T. (2002). The phylogeny of colpodellids (Alveolata) using small subunit rRNA gene sequences suggests they are the free-living sister group to apicomplexans. J. Eukaryot. Microbiol. 49, 498-504.

Leander, B. S., and Kuvardina, O. N. (2003). Molecular phylogeny and 
surface morphology of Colpodella edax (Alveolata): insights into the phagotrophic ancestry of apicomplexans. J. Eukaryot. Microbiol. 50, $334-340$.

Logares, R., Rengefors, K., Kremp, A., Shalchian-Tabrizi, K., Boltovskoy, A., Tengs, T., Shurtleff, A., et al. (2006). Phynotypically different microalgal morphospecies with identical ribosomal DNA: a case of rapid adaptive evolution. Microbial. Ecol. 53, 549-561.

Ma, Y., Galinski, E., Grant, W., Oren, A., and Ventosa, A. (2010). Halophiles 2010: Life in Saline Environments. Appl. Enviorn. Microbiol. 76, 6971-6981.

Macumber, P. G. (1991). Interaction Between Groundwater and Surface Systems in Northern Victoria. Melbourne, VIC: Department of Conservation and Environment, 345.

Macumber, P. G. (1992). Hydrological processes in the Tyrrell Basin, southeastern Australia. Chemical Geol. 96, 1-18.

Medinger, R., Nolte, V., Pandey, R. V., Jost, S., Ottenwälder, B., Schlötterer, C., et al. (2010). Diversity in a hidden world: potential and limitation of next-generation sequencing for surveys of molecular diversity of eukaryotic microorganisms. Mol Ecol 19(Suppl. 1), 32-40.

Medlin, L., Elwood, H. J., Stickel, S., and Sogin, M. L. (1988). The characterization of enzymatically amplified eukaryotic 16S-like rRNA-coding regions. Gene 71, 491-499.

Mylnikov, A. P. (2009). Ultrastructure and phylogeny of colpodellids (Colpodellida, Alveolata). Biol. Bull. Russ. Acad. Sci. 36, 582-590.

Narasingarao, P., Podell, S., Ugalde, J. A., Brochier-Armanet, C., Emerson, J. B., Brocks, J. J., et al. (2011). De novo metagenomic assembly reveals abundant novel major lineage of Archaea in hypersaline microbial communities. ISME J. 6, 81-93.

Olmos, J., Ochoa, L., Paniagua-Michel, J., and Contreras, R. (2009). DNA fingerprinting differentiation between beta-carotene hyperproducer strains of Dunaliella from around the world. Saline Syst. 5:5. doi: 10.1186/1746-1448-5-5

Olmos, J., Paniagua, J., and Contreras, R. (2000). Molecular identification of Dunaliella sp. utilizing the $18 \mathrm{~S}$ rDNA gene. Lett. Appl. Microbiol. $30,80-84$.

Oren, A. (2005). A hundred years of Dunaliella research: 1905-2005. Saline Syst. 1, 2.

Oren, A., Gurevich, P., Anati, D. A. Barkan, E., and Luz, B. (1995). A bloom of Dunaliella parva in the Dead Sea in 1992: biological and biogeochemical aspects. Hydrobiologia 297, 173-185.

Park, J. S., Kim, H., Choi, D. H., and Cho, B. C. (2003). Active flagellates grazing on prokaryotes in high salinity waters of a solar saltern. Aquat. Microb. Ecol. 33, 173-179.

Park, J. S., and Simpson, A. G. B. (2010). Characterization of halotolerant Bicosoecida and Placididea (Stramenopila) that are distinct from marine forms, and the phylogenetic pattern of salinity preference in heterotrophic stramenopiles. Environ. Microbiol. 12, 1173-1184.

Patterson, D., and Simpson, A. (1996). Heterotrophic flagellates from coastal marine and hypersaline sediments in Western Australia. Eur. J. Protistol. 32, 423-448.

Pedrós-Alió, C., Calderón-Paz, J., MacLean, M., Medina, G., Marrasé, C., Gasol, J., et al. (2000). The microbial food web along salinity gradients. FEMS Microbiol. Ecol. 32, 143-155.

Podell, S., Ugalde, J. A., Narasingarao, P., Banfield, J. F., Heidelberg, K. B., and Allen, E. E. (2013) Assemblydriven community genomics of a hypersaline microbial ecosystem. PLoS ONE 8:e61692. doi: 10.1371/journal.pone.0061692.

Post, F., Borowitzka, L., Borowitzka, M., and Mackay, B. (1983). The protozoa of a Western Australian hypersaline lagoon. Hydrobiologia 105, 95-113.

Potter, A. T., Palmer, M. W., and Henley, W. J. (2006). Diatom genus diversity and assemblage structure in relation to salinity at the Salt Plains National Wildlife Refuge, Alfalfa County, Oklahoma. Am. Midland. Nat. 156, 65-74.

Prokopowich, C. D., Gregory, T. R., and Crease, T. J. (2003). The correlation between rDNA copy number and genome size in eukaryotes. Genome $46,48-50$.
Pruesse, E., Quast, C., Knittel, K., Fuchs, B., Ludwig, W., Peplies, J., and Glöckner, F. O. (2007). SILVA: a comprehensive online resource for quality checked and aligned ribosomal RNA sequence data compatible with ARB. Nucleic Acids Res. 35, 7188-7196.

Quast, C., Pruesse, E., Yilmaz, P., Gerken, J., Schweer, T., Yarza, P., et al. (2013) The SILVA ribosomal RNA gene database project: improved data processing and webbased tools. Nucleic Acids Res. 41, D590-D596.

Ramos, A., Polle, J., Tran, D., Cushman, J., and Jin, E. (2011). The unicellular green alga Dunaliella salina Teod. as a model for abiotic stress tolerance: genetic advances and future perspectives. Algae. 26, 3-20

Rusch, D. B., Halpern, A. L., Sutton, G., Heidelberg, K. B., Williamson, S., Yooseph, S., et al. (2007). The Sorcerer II Global Ocean Sampling expedition: northwest Atlantic through eastern tropical Pacific. PLoS Biol. 5:e77. doi: 10.1371/ journal.pbio.0050077

Schloss, P. D., Westcott, S. L., Ryabin, T., Hall, J. R., Hartmann, M., Hollister, E. B., et al. (2009). Introducing Mothur: open source, platform independent, community supported software for describing and comparing microbial communities. Appl. Environ. Microbiol. 75, 7537-7541.

Simpson, A. G. B., and Patterson, D. J. (1996). Ultrastructure and identification of the predatory flagellate Colpodella pugnax Cienkowski (Apicomplexa) with a description of Colpodella turpis n. sp. and a review of the genus. Syst. Parasitol. $33,187-198$.

Tamura, K., Peterson, D., Peterson, N., Stecher, G., Nei, M., and Kumar S. (2011). MEGA5: molecular evolutionary genetics analysis using maximum likelihood, evolutionary distance and maximum parsimony methods. Mol. Biol. Evol. 28, 2731-2739.

Terrado, R., Medrinal, E., Dasilva, C., Thaler, M., Vincent, W., and Lovejoy, C. (2011). Protist community composition during spring in an Arctic flaw lead polynya. Polar Biol. 34, 1901-1914.

Ventosa, A. (2006). "Unusual micro-organisms from unusual habitats:hypersaline environments," in SGM Symposium 66: Prokaryotic Diversity - Mechanisms and Significance, eds N. A. Logan, H. M. Lappin-Scott, and P. Oyston (Cambridge, MA: Cambridge University Press), 223-253.

Wang, Q., Garrity, G., Tiedje, J., and Cole, J. (2007). Naive Bayesian classifier for rapid assignment of rRNA sequences into the new bacterial taxonomy. Appl. Environ. Microbiol. 73, 5261-5267.

Winge, R., Patterson, V., and Fassel, V. (1979). Inductively coupled plasma-atomic emission spectroscopy: prominent lines. Appl. Spectrosc. 33, 206-219.

Woelkerling, W. J., Kowal, R. R., and Gough, S. B. (1976). Sedgwickrafter cell counts: a procedural analysis. Hydrobiologia 48, 95-107.

Zalar, P., de Hoog, G. S., Schroers, H. J., Frank, J. M., and GundeCimerman, N. (2005). Taxonomy and phylogeny of the xerophilic genus Wallemia (Wallemiomycetes and Wallemiales, cl. et ord. nov.). Antonie Van Leeuwenhoek 87, 311-328.

Conflict of Interest Statement: The authors declare that the research was conducted in the absence of any commercial or financial relationships that could be construed as a potential conflict of interest.

Received: 31 July 2012; accepted: 24 April 2013; published online: 13 May 2013. Citation: Heidelberg KB, Nelson WC, Holm JB, Eisenkolb N, Andrade $K$ and Emerson JB (2013) Characterization of eukaryotic microbial diversity in hypersaline Lake Tyrrell, Australia. Front. Microbiol. 4:115. doi: 10.3389/fmicb. 2013.00115

This article was submitted to Frontiers in Aquatic Microbiology, a specialty of Frontiers in Microbiology.

Copyright (c) 2013 Heidelberg, Nelson, Holm, Eisenkolb, Andrade and Emerson. This is an open-access article distributed under the terms of the Creative Commons Attribution License, which permits use, distribution and reproduction in other forums, provided the original authors and source are credited and subject to any copyright notices concerning any third-party graphics etc. 